\section{Model Development on the Sustainable Financial Aspects of Urban Polders in the Province of DKI Jakarta}

\author{
Wied Wiwoho Winaktoe ${ }^{a^{*},}$ Bart Schultz ${ }^{b}$, \\ F.X. Suryadi ${ }^{\text {b }}$
}

$a, b, c$ Chair Group of Land and Water Development, UNESCOIHE, 2601 DA Delft, The Netherlands

Received: October 4, 2015/ Accepted: October 26, 2017

\section{Abstract}

Financial aspects are a critical part of a sustainable urban polder system. This research aims to develop a model of the financial aspects with variable 'households which occupy floodplains' as a performance indicator. Further, measuring the key variables' effect and significance will enable an assessment of the financial situation and other key aspects across polders. Data was collected from the polders of Muara Karang, Duri Kosambi, Pulomas, and Pluit during the period 2009-2014. Partial Least Square (PLS) v. 3.2.3 is used to reach the objectives. This research found that: a model of financial aspects can statistically explain key variables involved and support the introduction of households occupying the floodplains as a performance indicator, as shown by $\mathrm{R}^{2}=94.5 \%$, hence, manipulating the indicators (Gov_bdg, PP, CPP) could affect the construct (Sust. Inf). The Gov_bdg >> PP segment is the only interaction which has an effect of +0.784 and is significant with a T-value of 6.956; this is the only segment which matches the expected weight sign $(+)$ as derived from theory and best practice. It means that the realization of the Government budget positively affects the business environment while other inter-segment relationships have not yet performed as expected and could not propagate sustainable infrastructure as shown by the insignificant T-value under a $5 \%$ level of confidence.

Keywords: financial; Jakarta; polder.

\footnotetext{
* Corresponding Author

Tel.: +6281294413339 ; E-mail: motogaeri@gmail.com
}

\begin{tabular}{|lll|}
\hline Abbreviations: & \\
& $:$ & Daerah Khusus Ibukota (Special Capital \\
TBL & $:$ & Tegion) \\
CSR & $:$ & Corporate Social Responsibility \\
St.Dev. & $:$ & Standard Deviation \\
PLS & $:$ & Partial Least Square \\
Gov_bdg & $:$ & Government budget for flood protection \\
& & and drainage control \\
PP & $:$ & Partnership potentiality \\
CPP & $:$ & Community participation potentiality \\
Sus. Inf. & $:$ & Sustainability of flood protection and \\
& & drainage infrastructures \\
MK & $:$ & Muara Karang \\
KOS & $:$ & Duri Kosambi \\
PM & $:$ & Pulomas \\
PL & $:$ & Pluit \\
bdg & $:$ & indicator of Government budget for flood \\
& & protection and urban drainage \\
sme & $:$ & indicator of number of enterprises \\
_mrw & $:$ & indicator of number of households whose \\
& & wages are above the Minimum Regional \\
& Wage & indicator of number of households that \\
is & occupy the floodplains \\
RSCEP & $:$ & Research Centre for \\
& & Empowerment and Participation \\
RCSEE & $:$ & Research Center for Social, Economic and \\
POWRM & $:$ & Provincial Office of Water Resources \\
& & Management \\
\hline
\end{tabular}

\section{Introduction}

After 48 years of polder development in the Province of DKI Jakarta (1965-2011) a start has been made to incorporate issues of sustainability into the Spatial Planning document of DKI Jakarta 2010-2030 [1]. Outside of the technical aspects, which are considered to be sufficiently understood, the academic draft of the document expected that financial and institutional aspects would have to be formulated according to a Polder Board Model as the precedent. Financial aspects were described such that water management needs to be undertaken in a sustainable way, with greater public/community participation, and self financing. Stakeholders would have to contribute and have the right to determine policy at polder level through the principle of benefit-pay-say [2]. From a good governance perspective, these concepts need to be translated into a glass-box type planning model in which every stakeholder can transparently follow the dynamic. 


\section{Demand for polder's Sustainable Financial Model (SFM)}

\subsection{Good Governance principles towards the stage of community participation}

Financial aspect in term of community participation through polder tax needs to be planned by Governmental Offices with a solid theoretical and empirical basis as it involves a public budget and has time constraint. It is mandatary to comply the good governance principles [3] especially as follows [4]: transparency (program announcement to public), participatory (ensure public access/hearing to policy making) [5], and accountability (be responsible according to the internal-control and accountancy system) [6].

Indonesia polder development adopted a comprehensive approach by formulating the concept in year 2001 through Banger Polder Pilot Project, in Central Java [7]. This pilot and its accompanying activities produced the urban polder guidelines as the primary and most complete reference which consisted the aspects of technical, financial, legal, and institutional. The guidelines were products of collaboration between Indonesia (Research Center for Water Resources, Directorate General for Spatial Planning, Semarang Municipality Offices of Public Works and Planning Board, Chatolic University of Parahyangan) and The Netherlands (Rijkwaterstaat and UNESCO-IHE, Delft). In year 2010, the aspects of financial, legal, and institutional were delivered to Research Centre for Community Empowerment and Participation (RSCEP, Pusebranmas) under Ministry of Public Works [8], which had successfully develop stakeholder's commitment and multi Governmental-Offices task force in land consolidation and housing resettlement project during period of 2008-2011 [9]. RSCEP was expected to formulate a financial-legalinstitutional model which can be utilized as an Indonesia National Standard. The research was postponed due to various reasons, mainly because reorganization of RSCEP into Research Center for Social, Economic and Environment (RCSEE) however the new demand for the model shall come from the good governance principles and a scientific reference on which a various stakeholder, under future polder board, can communicate with.

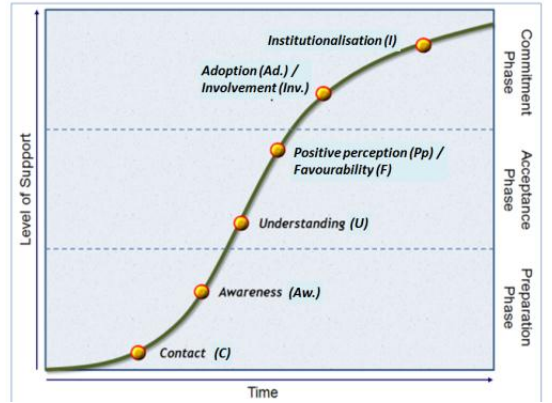

Figure 1 Six staged stakeholder's commitment curve (After Conner, Daryl R. and Patterson, Robert W, 1982) [18]

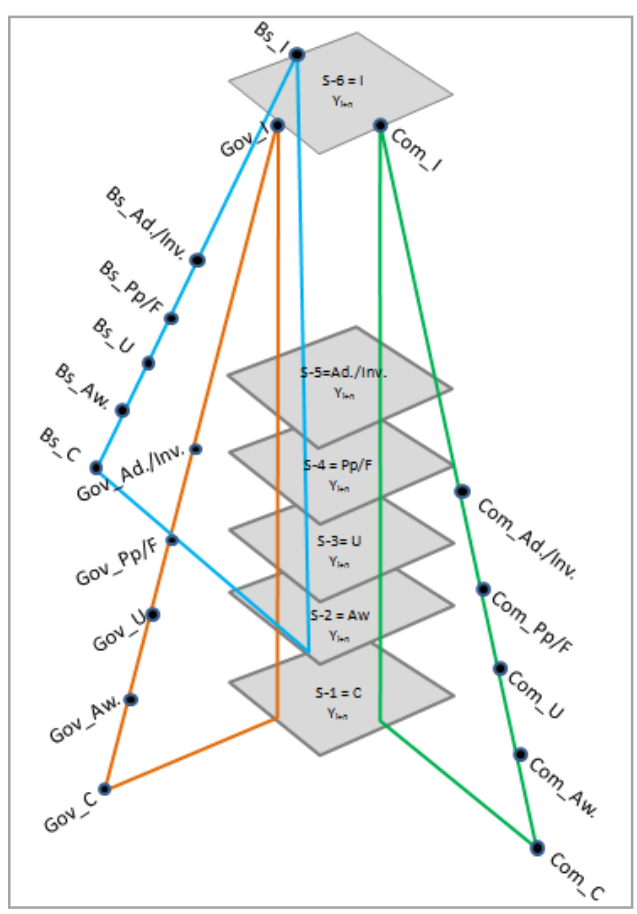

\begin{tabular}{ll}
\hline Legend & \multicolumn{1}{c}{ Description } \\
\hline Gov__ & : Government \\
Bs__ & : Business sector \\
Com__ & : community \\
S -n & : Stage at year n \\
_ & : stage 6 of institutionalisation \\
_Ad/Inv & $:$ stage 5 of adaptation/involvement \\
_Pp/F & $:$ stage 4 of positive perception/ favourability \\
_U & : stage 3 of understanding \\
_Aw & $:$ stage 2 of awareness \\
${ }_{-}$C & $:$stage 1 of concact
\end{tabular}

Figure 2 Stakeholders'commitment curve for polder development

The urban polder guidelines actually provided advices on financial aspect's stages of polder board which were realisation and management phases [10] however, as compared to the commitment curve theory (Figure 1) as 
verified by RSCEP [11], they were categorized as more advanced stages of which could only be attained after certain preceding stages are completed as described in PIK and MK cases (Figure 2 and 3). In practice, Banger Polder struggled towards community participation [12] and decided to apply a policy [13] of which actually in accordance with the commitment curve theory by permitting the inhabitants for paying the polder tax after certain times of properly functioning polder [14] or the first 10 years shall be paid by Board of Regional Planning and Development [15].

In year 2011, Provincial Government of DKI Jakarta published the Jakarta Coastal Defence Strategy (JCDS) document in which polder is established as a flood control strategy for low lying areas [16]. Long before that, two polders, privately Pantai Indah Kapuk (PIK) and publicly Muara Karang (MK), have been operating and were considered as best practices of polder management. What DKI Jakarta's JCDS and academic draft of Spatial Planning 2010-2030 concept expected were similarly an advancing stage as well which was sustainable polder institution through community self financing [17]. This is equal to 6th stage (institutionalisasion) of the commitment curve theory and by experience, as PIK's and MK's, might only be achieved after completing certain stages and could be maintained under multi factors interactions as expressed in PLS schematic (Figure 4).

(a)

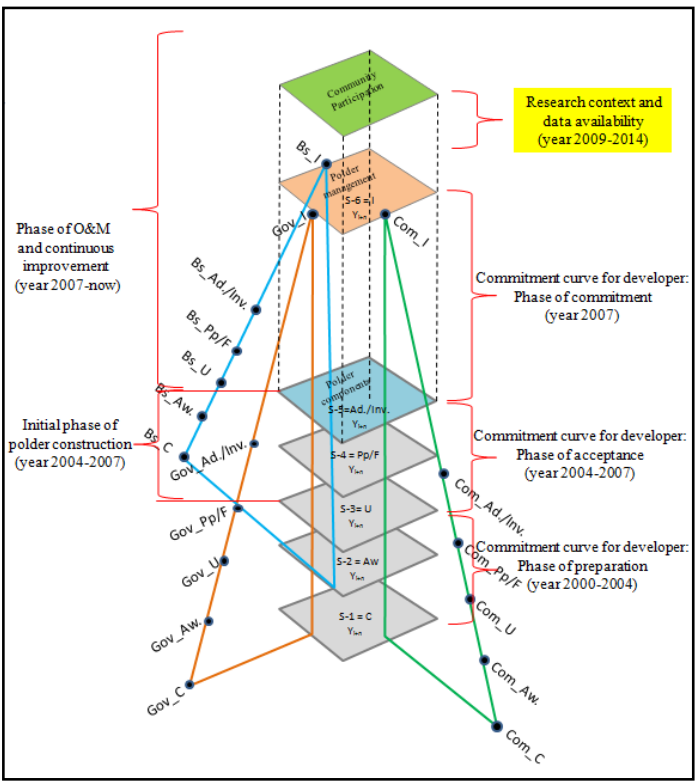

(b)

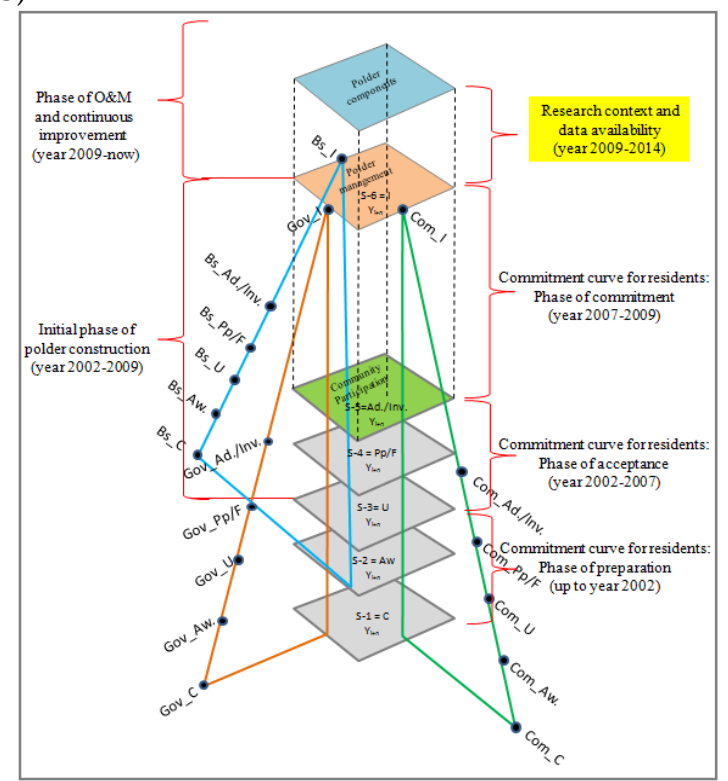

Figure 3 Stages of commitment towards community participation of (a) PIK and (b) MK

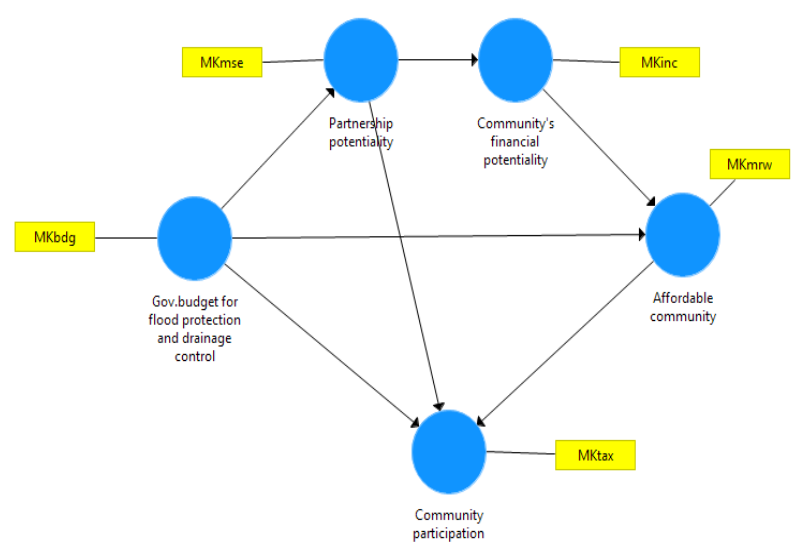

Figure 4 PLS's schematic of enabling factors for PIK's and MK's polder tax payment

Various variants of SFM are needed as there are various stages and measured indicators ( $\mathrm{Y}$ in SEM-PLS) along the process towards the institutionalized polder board and community participation. Nevertheless, to this point, (i) the theoretical approach of which SFM may be continuously developed and (ii) empirical stages of which had been undertaken by the successful polder cases are available. 


\subsection{Platform for multi-Governmental stakeholders}

Despite the vision of SFM has already described in the academic draft of Spatial Planning 2010-2030 however the executing agency was not explicitely assigned. The DKI Jakarta Provincial Office of Water Resources Management (POWRM) would be involved and could lead as previous experience in Banger Pilot Polder, Central Java. Considering that certain factors of SFM are not merely structural measures which have been officially POWRM's compentencies then the role of other Governmental stakeholders/Offices to take a part become possible [19]. In that condition, a capacity improvement of managing the non-structural measures is unavoidably needed by POWRM.

Moreover, as it shall turn into a collaborative work then a platform for the Governmental policy-cycle of planningbudgetting-implementation-evaluation [20] would be required as a communication tool, and each member's performance indicator [21]. For the former, the SFM can fulfil that requirement in terms that its predictors (X) shall represent each Governmental Offices' program while the measured indicators $(\mathrm{Y})$ represents the goal or expected condition. For the latter, the SFM's weight and T-value could contribute as measured effectiveness or impact of the programs which have been implemented after certain periods.

\section{Sustainability substance in the model}

\subsection{Alleviation of households who occupy the floodplain as an indicator for sustainable flood protection and urban drainage}

A polder is a level area, in its original state subject to high water levels (permanently or seasonally, originating from either groundwater or surface water), but which through impoldering is separated from its surrounding hydrological regime in such a way that a certain level of independent control of its water table can be realized' [22]. A polder system consists of dikes, drains, retention ponds, outfall structures or pumping stations and other components that create one integrated system as shown in Figure 5 [23].

Financial aspect practice is conceptualized, based on the cases of PIK and MK polders, the interactions between Government, the private sector, and community as follows: dikes, retention ponds, and urban drainage are provided by the Government, pumps and pumping stations are provided either by Government or the private sector through Corporate Social Responsibility (CSR). An operator fee is provided by the stakeholders, including the community [24].

Empirically, these polder components have been an attractive object by the households who occupied the floodplains (illegal dwellers) as they cannot afford land in the formal market. Through their jobs and requested assistance priority then that kind of households are reality due to under develop economic [25]. MK and Pluit polders used to have 500 (year 2002) and 70-90 illegal dwellers respectively (year 2002-2014) [26]. The growth of illegal settlement turned the rivers and retention ponds into narrow, sedimentation is occurring intensively, and urban drainages are disappearing or clogging due to solid waste. These impacts threaten the polder system, increase the risk of malfunction, and can render the infrastructure ineffective for the long term.

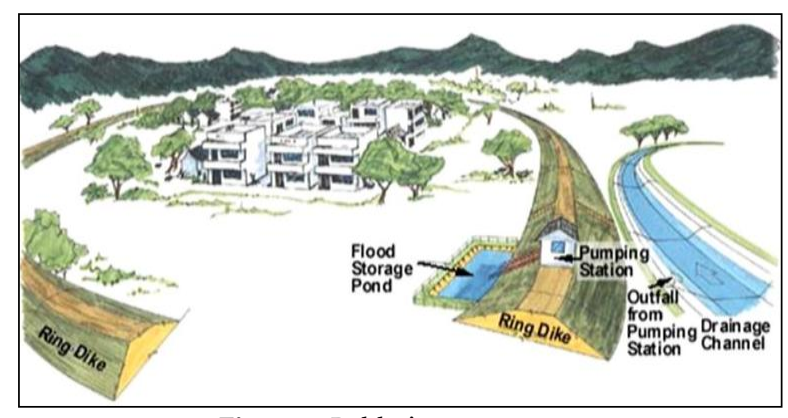

Figure 5 Polder's components

Sustainable flood protection and urban drainage of polders may have different performance indicators according to the stage of development they pass through. In long term (stage $6^{\text {th }}$ of the commitmen curve theory), ideally, continuity to pay a polder tax would become a performance indicator however for the current time, as illegal dwellers still occupy the urban polders's components then it needs to utilize indicator reflecting this stage of development, i.e. households who occupy the floodplains [27].

\subsection{Triple Bottom Line (TBL) and scale-up potentiality}

The model of financial aspects for sustainable flood protection and urban drainage infrastructure in the urban polders may affect environmental aspects in the sense that when the number of households who occupy the floodplain is significantly decreased, as the model is going to indicate, then the water body (storage ratio) condition may also be improved due to less solid waste dumping. Also, contagious diseases may be prevented due to a less densely populated area, less low quality housing and reduced polluted air movement.

With regard to socio-economic aspects, the model may bring the interactions between Government, the private sector and community together, to enhance cohesiveness and minimize social gaps by giving opportunity to the households who occupy the floodplains to access programs and jobs provided by public or private sector actors [28]. 
Further, the expected effect from Governmental budget realization, the business environment and community participation (households whose wages exceed the Regional Minimum Wage) are systematically observed to maintain optimum conditions where the performance of infrastructure can be improved to ensure benefit for the lowest income groups, enabling them to contribute [29]. With regard to institutional aspects, this model may give integrated directions for various DKI Jakarta Provincial offices whose tasks are related (among other things) to small and medium enterprise, water resources, water quality, public housing, public health and social welfare.

The model can help to set the Provincial baseline of the Governmental budget's effect towards business growth or other targets. Further, this baseline may be used to evaluate individual polder performance as well. The integrated features of this model may also bring a consolidated vision for various Provincial Offices which are engaged in polder development. The method and this model's development are applicable to other polder areas within the country of Indonesia, hence scaling-up of the model is also possible.

\section{Research Question}

Following the previous sub sections (3.1 and 3.2), this research aims at developing a model of the financial aspects with variable 'households which occupy floodplains' as a performance indicator. This indicator not only fits the current conditions of urban polders in DKI Jakarta but may bring the financial aspect's stakeholders towards a higher level and model type with another suitable indicator, such as continuity of polder tax payment.

As the financial aspects of polder (relationships among Government budget for flood protection and urban drainage, partnership potentiality and community participation potentiality) are critical for sustainable flood protection and drainage hence encourage transparent policy and reliable program for urban polder of DKI Jakarta then the research question: what are the general baseline and performance of those financial aspect in sustaining the urban polders for DKI Jakarta?

\section{Research Method}

By considering the feature of interactions which is multitudes and objective to have a robust foundation for policy-cyles (sub section 2.1. and 2.2.) then the model type of this research is primarily a mathematical model. The model shall emulate interactions among Government budget for flood protection and drainage control, partnership potentiality, and community participation to explain the financial sustainability of polders as measured by indicator of households who occupy the floodplains (section 3.1).

Prior to use SEM-PLS for modeling this particular financial aspects of polders, several methods were tested namely non-parametric statistical correlations [30] and composite index [31]. Both were capable of portraying the financial aspects characteristics comparatively but had limitations in relation with multi-factors interactions which lead to inability in providing options for various policy scenarios. Scenario development is necessary as this model is intended as a basis for policy-cycle (sub section 2.2). SEMPLS, through is path analysis, is equipped with capability of providing direct/indirect effects [32] which can be translated into alternative policy scenarios as in reality Government always deals with budget, institutional and time constraints. The schematic feature of SEM-PLS is also useful for communicating the results to various stakeholders with different backgrounds. Limited available data (periode 2009-2014) became another cause for utilizing the SEM-PLS as it is advantagous for small sample size [33].

\subsection{Model development}

Preliminary analysis identified that the ability to develop, operate and maintain the urban polder corresponded with partnerships and stakeholder affordability, as well as reduction of illegal structures in the floodplain [34]. As the Government budget is the primary source of development financing, in order to be successful, it needs to stimulate the essential features of the Polder Board model, based on a partnership between the stakeholders. Therefore, allocation of the budget for flood protection and urban drainage (Gov_bdg) has to be made in such a way that it attracts business sectors (partnership potentiality, PP) which are expected to increase the financial affordability for inhabitants (community participation potentiality, CPP). In addition decrease reduction of illegal structures in the floodplain is required (sustainability of flood protection and drainage infrastructure, Sust. Inf.). 


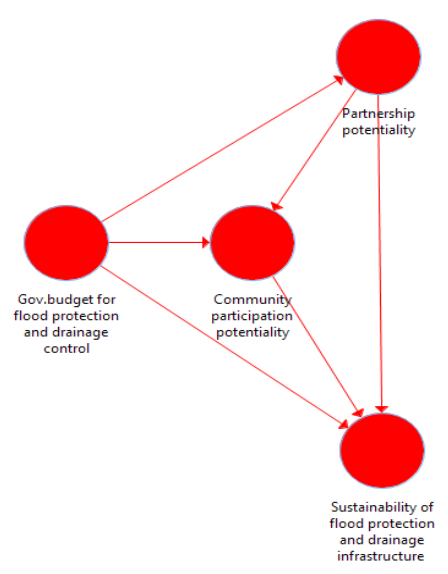

Figure 6 Model configuration using PLS v. 3.2.3

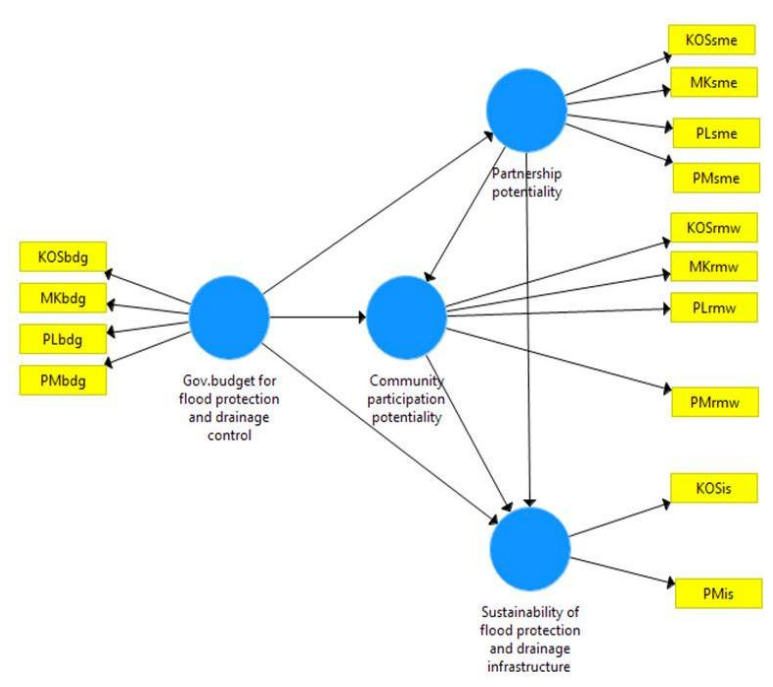

Figure 7 Latent, manifest variables and predictors using PLS v. 3.2 .3

Table 1 Predictors, construct and indicators

\begin{tabular}{ll}
\hline \multicolumn{1}{c}{ Predictors and Construct } & Indicators \\
\hline \multirow{2}{*}{ Predictor $\left(\mathrm{X}_{1}\right)$ : } & MKbdg \\
& KOSbdg \\
Government budget for flood protection & PMbdg \\
and drainage control (Gov_bdg) & PLbdg \\
Predictor (X2): & MKsme \\
Partnership potentiality (PP) & KOSsme \\
& PMsme \\
& PLsme \\
\hline
\end{tabular}

Table 1 Continued

\begin{tabular}{ll} 
Predictor $\left(\mathrm{X}_{3}\right)$ : & MKrmw \\
Community participation potentiality & KOSrmw \\
$(\mathrm{CPP})$ & PMrmw \\
& PLrmw \\
Response or Construct (Y): & MKis \\
Sustainability of flood protection and & KOSis \\
drainage infrastructures (Sus. Inf.) & PMis \\
& PLis \\
\hline
\end{tabular}

Table 2 Indicators' St. Dev. $\left(s^{2}\right)$ and variance $(s)$

\begin{tabular}{lcrrr}
\hline Code & Unit & $\begin{array}{c}\text { Indicators } \\
\text { St.Dev. } \\
\left(s^{2}\right)\end{array}$ & $\begin{array}{c}\text { Variance } \\
(s)\end{array}$ & Remarks \\
\hline MKbdg & Rp.X 10 $^{6}$ & 890.0 & 94.2 & Included \\
KOSbdg & & $8,600.0$ & 92.5 & Included \\
PMbdg & & $2,090.0$ & $45 \cdot 7$ & Included \\
PLbdg & & 4,380 & 66.2 & Included \\
MKsme & & 118 & 10.9 & Included \\
KOSsme & Enterprises & 60.3 & 7.77 & Included \\
PMsme & & 13.6 & 3.66 & Included \\
PLsme & & 4.45 & 2.11 & Included \\
MKrmw & & 1.47 & 1.21 & Included \\
KOSrmw & $\%$ & 11.8 & 3.44 & Included \\
PMrmw & & 1.66 & 1.29 & Included \\
PLrmw & & 0.10 & 0.32 & Included \\
MKis & & 0.00 & 0.00 & Excluded \\
KOSis & & 24 & 4.90 & Included \\
PMis & Households & 1,270 & 35.6 & Included \\
PLis & & 0.00 & 0.00 & Excluded \\
\hline
\end{tabular}

The relationship between constructs and predictors are configured using Partial Least Square (PLS) software v. 3.2.3 as shown in Figure 6 then combined with indicators as shown in Figure 7. The case studies involve the polders of Muara Karang (MK), Duri Kosambi (KOS), Pulomas (PM) and Pluit-downstream (PL). In order to estimate each segment's Weight and T-value, certain indicators specific to each case study are determined as follows (see Table 1 and 2): Government budget for flood protection and urban drainage (bdg), number of enterprises (sme), number of households whose wages are above the Minimum Regional Wage (mrw) and number of households that occupy the floodplain (is). Data was collected from the years 2009-2014, 6 years for each indicator. As data samples are less than 15 (years) in duration, non-parametric statistics are used in the PLS software, as it was designed for. The model fit test will use the $\mathrm{R}^{2}$ value [35]. 


\subsection{Model analysis}

In order to answer the research question on general baseline and performance then the Weight values and T-value shall be applied correspondingly. Prior to do that tasks, a model itself needs to have a reliability check through model fit (explanatory power value, $\mathrm{R}^{2}$ ). Weight reflects the covariance structure between predictors and response (construct, Y). The T-value measures the size of the difference relative to the variation in sample data. The greater the magnitude of $\mathrm{T}$, the greater the evidence against the null hypothesis that there is no significant difference. Effect and significance are identified respectively by weight and T-value (at a $5 \%$ level of confidence).

\section{Results}

The explanatory power $\left(\mathrm{R}^{2}\right)$ of this model is 0.945 which is considered very good due to a $94.5 \%$ data variability which can be explained by its predictors (Figure 8 ). This means that the selected construct-predictors-indicators and their configuration are suitable for understanding the situation.

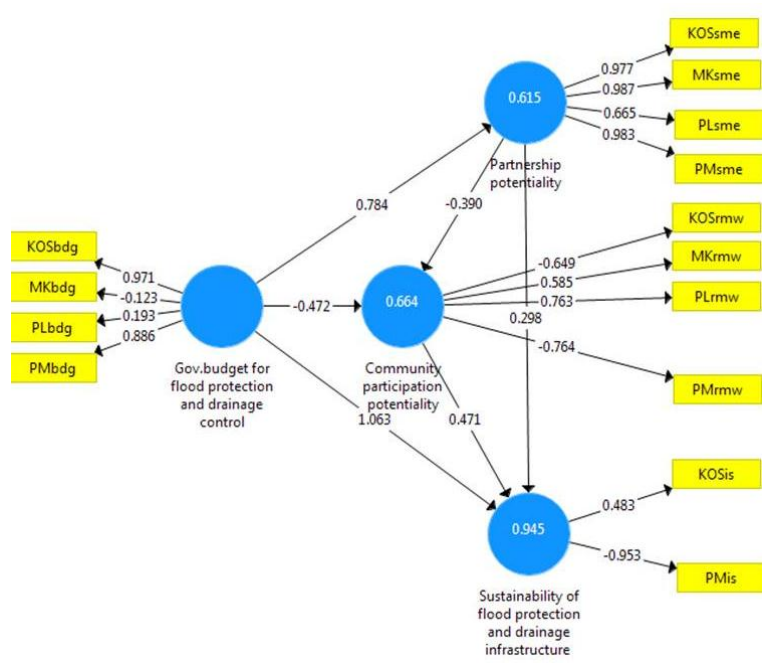

Figure 8 Weight value

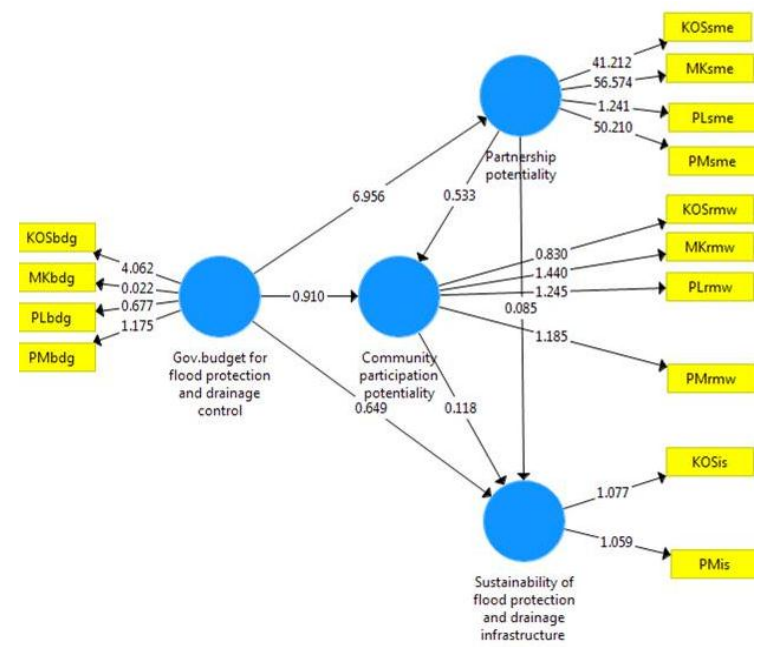

Figure 9 T-value

Table 3 Weight, T-value and Significance

\begin{tabular}{|c|c|c|c|c|}
\hline Segment & Weight & $\begin{array}{c}\text { Expected } \\
\text { Weight } \\
\text { Sign }\end{array}$ & $\begin{array}{c}\text { T- } \\
\text { value } \\
\text { (stat) }\end{array}$ & $\begin{array}{c}\text { Significance at } \\
\alpha=5 \% \text { or T- } \\
\text { value (table) }= \\
1.96\end{array}$ \\
\hline $\begin{array}{l}\text { Gov_bdg >> } \\
\text { PP }\end{array}$ & +0.784 & + & 6.956 & significant \\
\hline $\begin{array}{l}\text { Gov_bdg >> } \\
\text { CPP }\end{array}$ & -0.472 & + & 0.910 & insignificant \\
\hline $\begin{array}{l}\text { Gov_bdg >> } \\
\text { Sus. Inf. }\end{array}$ & +1.063 & - & 0.649 & insignificant \\
\hline $\mathrm{PP}>>\mathrm{CPP}$ & -0.390 & + & 0.533 & insignificant \\
\hline $\begin{array}{l}\text { PP }>> \\
\text { Sus. Inf. }\end{array}$ & +0.298 & - & 0.085 & insignificant \\
\hline $\begin{array}{l}\text { CPP }>> \\
\text { Sus. Inf. }\end{array}$ & +0.471 & - & 0.118 & insignificant \\
\hline
\end{tabular}

All weight results in Table 3 are the general baseline of financial aspects for polders in DKI Jakarta at the time of calculation. Differences between sign in weight results and expected sign indicate a qualitative historical performance comparison meaning that for periode of 2009-2014 further improvement needs to be applied to segments Gov_bdg >> Sus. Inf., PP $>>$ CPP, PP $>>$ Sus. Inf., CPP $>>$ Sus. Inf.

Gov_bdg > PP (Weight $=+0.784$ ) is the only segment whose sign is match with the expected sign. It means that budget realization for flood protection and urban drainage reach a level of enabling in relation with the partnership potentiality. Empirically, tabel 4 shows that in all polders the trends for Gov_bdg are similar to PP's trends. Exception for polder Muara Karang (MKbdg) was due to completeness of flood protection system before periode of 2009-2014 that made decreasing trend of Government budget realization to that polder. 
Table 4 Average growth per year of Gov.bdg and PP during the period 2009-2014

\begin{tabular}{llr}
\hline Predictors & \multicolumn{1}{c}{ Indicators } & Average growth per year \\
\hline Gov_bdg & MKbdg $\left(\times 10^{6}\right)$ & -70.00 \\
& KOSbdg $\left(\mathrm{x} \mathrm{10}^{6}\right)$ & +4205.00 \\
& PMbdg $\left(\mathrm{x} \mathrm{10}^{6}\right)$ & +720.00 \\
& PLbdg $\left(\mathrm{x} \mathrm{10} 0^{6}\right)$ & +467.50 \\
PP & MKsme & +63.00 \\
& KOSsme & +29.00 \\
& PMsme & +7.00 \\
& PLsme & +2.00 \\
\hline
\end{tabular}

Regarding the general performance of the financial aspect, only Gov_bdg $\gg$ PP $($ T-value $=6.956)$ has a significant effect. It means that in general, budget realization for flood protection and urban drainage effectively stimulates the development of partnership potentiality. As the later is measured by the growth of enterprises then the former, polder infrastructure, has steadily impacted for ensuring a component of partnership with private sector for sustainable financing of urban polder. However, this partnership potentiality merely reach a level of existence which is not yet steadily contribute towards CPP or Sust.Inf

The remaining segments are insignificant meaning that, in general, their (exogens) contribution towards others (endogens) are neither yet effective nor steady. These impact at lacking the component of adequate (a) partnership potentiality ( $\mathrm{PP}>>\mathrm{CPP}, \mathrm{PP}>>$ Sus. Inf) and (b) community participation (Gov_bdg > CPP, PP > CPP) hence both risk the sustainability of urban polder infrastructure in term of alleviating the illegal dwellers from the floodplains (Gov_bdg $>>$ Sus. Inf., PP $>>$ Sus. Inf., CPP $>$ Sus. Inf.).

\section{Conclusion}

The polder's SFM can statistically explain the key variables involved in polder management, and supports the introduction of households occupying the floodplains (_is) as a performance indicator for the current stage of urban polder development in DKI Jakarta, as shown by the $\mathrm{R}^{2}$ value of $94.5 \%$. Since the model portray interactions among Gov_bdg, PP, CPP which head to end-route of Sust.Inf then manipulating those predictors may lead to an improved condition of polder infrastructure.

Based on periode 2009-2014 policy implementation, the baseline for DKI Jakarta urban polders' financial aspect are: +0.784 for Gov_bdg $>>$ PP, -0.472 for Gov_bdg $>$ CPP, +1.063 for Gov_bdg $>>$ Sus. Inf., -0.390 for PP $>$ CPP, +0.298 for PP $>>$ Sus. Inf., +o.471 for CPP >> Sus. Inf. POWRM and relevant agencies could utilize this information to keep positive the effect of Gov_bdg to PP for the next periode while start to either evaluate or include all necessary programs to attain expected signs and significances. If the stakeholders would make difference, by consensus, to increase Sust.Inf (reduce the _is) then they could reach that through turning into negative the direct effect's loading factor of Gov_bdg $\gg$ S Sus. Inf., PP >> Sus. Inf., CPP $>>$ Sus. Inf.

The baseline of DKI Jakarta urban polders' financial aspect may act as the general initial-performances to which all individual polders across DKI Jakarta may be evaluated on. Municipalities Offices and Agencies, below Provincial level, are therefore in particular, need to assess their budget realization according to, for instance, segment Gov_bdg >> PP which has already attained the level of effective and steady.

Despite of its utilization feature, what the most important is for the time being would be the model availability itself as a multi-stakeholder's platform for sustainable polder-infrastructure policy development. Through its loading factor (Weight, expected sign, and Tvalue), public and non-POWRM agencies are enabled equally to propose a plan and evaluate the policy implementation after certain times using a common tool. This is a manifestation of transparency and participatory which are not only assigned by good governance principles but also substansial in Polder Board way of works.

This model translates theory and best practice into tangible interactions among the constructs, predictors, indicators in the field. Therefore, this model can be used to plan, implement, manage, monitor and evaluate the financial aspects of polder systems for the Provincial Government of DKI Jakarta.

\section{References}

$[1,17]$ Bappeda DKI Jakarta. Naskah akademik Rencana Tata Ruang Wilayah DKI Jakarta 2010-2030, Jakarta, Indonesia: Badan Perencanaan dan Pembangunan Provinsi DKI Jakarta; 12 Januari 2010, Chapter 5 .

[2, 10] Joint Working Group. Urban polder Guidelines Volume 2: Institutional aspects, Semarang, Indonesia: Balitbang PUPuslitbang SDA, Rijkswaterstaat, UNESCO-IHE; 2009, p. 34-44 and 37-39.

[3] Peraturan Menteri Pekerjaan Umum Nomor:44/PRT/M/2007 Tentang Pedoman Umum Pembinaan SDM Dalam Penerapan Prinsip-Prinsip Tata Kelola Pemerintahan Yang Baik Di Lingkungan Departemen Pekerjaan Umum

[4] Pedoman Tata Kelola Pemerintahan Direktorat Jenderal Cipta Karya Departemen Pekerjaan Umum

[5, 7] Helmer J. Final research report BPPB SIMA: Organization And Finance. p. 12. Rotterdam, The Netherlands: HHSK Rotterdam; 2011

[6] Raharja Sam'un Jaja. Paradigma Governance dalam penerapan manajemen kebijakan sektor publik pada pengelolaan sungai. Bisnis \& Birokrasi, Jurnal Ilmu Administrasi dan Organisasi, Volume 16, Nomor 2, ISSN o854-3844; Mei-Agustus 2009: 8286.

[8] Winaktoe Wied W, Irawati Miya. Laporan Polder Banger. Jakarta, Indonesia: Pusebranmas, Puslitbang Kementerian Pekerjaan Umum; 2009 
[9]AY Al Junaid. Laporan konsolidasi lahan Kelurahan Cigugur Tengah: Penyusunan Pedoman, Kota Cimahi. Yogyakarta, Indonesia: Balai Sosekkim, Puslitbang Sebranmas, Kementerian Pekerjaan Umum; 2011

[11, 18] AY Al Junaid. Laporan konsolidasi lahan Kelurahan Cigugur Tengah: Implementasi program, Kota Cimahi. Yogyakarta, Indonesia: Balai Sosekkim, Puslitbang Sebranmas, Kementerian Pekerjaan Umum; 2010

[12] Zulfanı James, Hana Maria Asunta. Pengelolaan Polder Banger berbasis kebersamaan antar stakeholder. Jurnal Sosial Ekonomi Pekerjaan Umum Vol. 5 No. 1; 2013: 39-50

[13] Anonim. Economic feasibility of Banger Pilot Polder development. p. 51. Semarang, Indonesia: Universitas Islam Sultan Agung; April 2008.

[14] Joint Working Group. Urban polder guidelines Vol. 4 Case study Banger Polder. Semarang, Indonesia: Balitbang PU-Puslitbang SDA, Rijkswaterstaat, UNESCO-IHE ; 2009, p. 58

[15] Van Ham RCB, Schuller ML. The social aspects in water management of the case Banger Polder pilot project and the new water board BPP SIMA. p.46. The Netherlands: Rotterdam University of Applied Sciences; 2014

[16]Anonim. Strategi pengamanan pantai Jakarta / Jakarta coastal defence strategy project (JCDS).Jakarta, Indonesia: Kementerian Pekerjaan Umum dan Partners for Water.2011, p. 1-28 and 3-18

[19] De Bruijn F. Market scan on the Indonesian water sector 'Opportunities and niches for the Dutch water sector'. p. 15. Deventer, The Netherlands: Witteveen+Bos ; 25 April 2012

[20] Smets Susanna. Turning finance into service for the future. p.1819. International Bank for Reconstruction and Development/The World Bank; 2015

[21] Wieriks Martijn. Water governance and policy networks in Indonesia. p. 43-65. Delft, The Netherlands: TU Delft; 2011

[22] Segeren WA. Polders of the World. Wageningen, the Netherlands: International Institute for Land Reclamation and Improvement; 1983.

[23] Joint Working Group. Urban polder guidelines Volume 1: General aspects, Semarang, Indonesia: Balitbang PU-Puslitbang SDA, Rijkswaterstaat, UNESCO-IHE; 2009, p. 7.

$[24,26,31,34]$ Winaktoe WW, Schultz B, Suryadi FX. DKI Jakarta's Polder development vision 2030: Assessing the progress and identifying policy needs based on the polder board model. Jakarta: Universitas Tarumanagara; 2015

[25] BPS DKI Jakarta. Analisis Tipologi Kemiskinan Perkotaan, Jakarta: Badan Pusat Statistik, 2007, p. 36 and 41

[27] Bricker Jeremy D, Kure Shuichi, Muhari Abdul, Fukutani Yo, Hanan Firmanto. Second report of IRIDeS fact-finding mission to Jakarta, Indonesia. p. 41. Japan: Tohoku University; 2013

[28]Muhtar Mansur, Majanen Pertti. Report of the intergovernmental committee of experts on sustainable development financing. p. 14. New York: United Nations; 2014

[29] Anonim. Using infrastructure development as a strategy for employment creation and poverty alleviation. Jakarta: ILO Jakarta and ASIST-AP; 2001

[30] Winaktoe Wied W, Schultz B, Suryadi FX. Assessment of DKI Jakarta's Budget Realization for Flood Protection and Urban Drainage Towards a Polder Board Vision. Bali, Indonesia: 6th International Conference on Sustainable Future for Human Security, SustaiN ; 2015

[32] Garson David G. Partial Least Squares: Regression \& Structural Equation Models. Asheboro, NC, USA: Statistical Publishing Associates; 2016: p. 28-29.
[33] Hair Jr Joseph F, Ringle Christian M, Sarstedt Marko. Partial Least Squares Structural Equation Modeling: Rigorous Applications, Better Results and Higher Acceptance. Long Range Planning, Vol 46 (2013) 1-12; 2013, p. 2

[35] Ghozali I, Structural Equation Modeling with Partial Least Square (PLS), Semarang, Indonesia: Badan Penerbit Universitas Diponegoro; 2011, p. 27. 